\title{
La estabilidad laboral reforzada de las mujeres trabajadoras en estado de embarazo: Colombia- México $^{1}$
}

\author{
Juan Carlos Berrocal Duran \\ Universitaria Rafael Núñez, Colombia \\ juan.berrocal@curnvirtual.edu.co \\ Jessica Jacqueline Casas Toscano \\ Universidad de Guadalajara, México \\ jackie2304.jc@gmail.com
}

Una vez hecho un análisis comparado de las legislaciones y criterios de las cortes constitucionales entre México y Colombia, con respecto a la estabilidad laboral reforzada de mujeres embarazadas, se pudo evidenciar que existen grandes similitudes y diferencias entre ambas, como se muestra a continuación.

La Constitución Política de los Estados Unidos Mexicanos en su artículo 1 párrafo $3^{\circ}$ y párrafo $5^{\circ}$, así como el artículo 13 de la Constitución Política de Colombia, garantizan la protección de los derechos humanos, así como, el derecho a la no discriminación de ningún tipo.

Del mismo modo, dichas constituciones protegen la igualdad entre hombres y mujeres ante la ley como un derecho fundamental, y están establecidas en el artículo $4^{\circ}$ de la Constitución mexicana y el artículo $43^{\circ}$ de la Constitución colombiana.

Ahora bien, tanto México como Colombia cuentan con una ley del

1 Este artículo es resultados del proyecto de investigación "Estabilidad Laboral Reforzada de las Mujeres Trabajadoras en estado de Embarazo", que se encuentra en curso, adscrito a la Línea de Investigación Justicia Constitucional, Derecho Penal y Responsabilidad del Estado desarrollada por el Grupo de Investigación Andrés Bello del Programa de Derecho de la Corporación Universitaria Rafael Núñez Sede Barranquilla. Juan Carlos Berrocal Duran del Programa de Derecho es el investigador responsables de este proyecto, contó con la coautoría de la estudiante Jessica Jacqueline Casas Toscano, de la Licenciatura de Derecho, de la Universidad de Guadalajara, sede Centro Universitario de Tonalá, (México), quien hace parte del Verano de la Investigación Científica y Tecnológica del Pacifico, del Programa Delfín. El proyecto fue financiado en su totalidad por la Corporación Universitaria Rafael Núñez 
trabajo, con la cual se protegen y regulan los derechos de los trabajadores. Por una parte, México cuenta con "La Ley Federal del Trabajo" y Colombia con "El Código Sustantivo del Trabajo".

En la comparación de estas dos legislaciones, se puede encontrar distintas diferencias y similitudes importantes para el análisis de la estabilidad laboral reforzada de mujeres embarazadas en ambos países.

Con respecto al análisis de esas dos legislaciones, la Ley Federal del Trabajo en su artículo 2 párrafo $4^{\circ}$ y $5^{\circ}$ de México, así como en el artículo 10 del Código Sustantivo del Trabajo, de Colombia, establecen análogamente, el principio a la no discriminación que constitucionalmente rige en ambos países.

En especial, la protección de la maternidad encuentra asidero en la Ley Federal del Trabajo en su artículo 165 y en el artículo 235-A del Código Sustantivo del Trabajo, dicha protección se encuentra de manera similar en ambas legislaciones, es decir, que ambos países concuerdan en que la protección principal al trabajo de las mujeres debe ser hacia la protección de la maternidad, principalmente.

Para el caso del periodo de lactancia, ambas legislaciones otorgan el derecho a un reposo extraordinario durante la jornada de trabajo, que se establece en los artículos Art. 170 fracción IV de la Ley Federal del Trabajo y Art. 238. 1. Del Código Sustantivo del Trabajo.

La principal conclusión que se tiene es que la estabilidad laboral reforzada consiste en que las mujeres en estado de embarazo puedan conservar su empleo. Por ello la legislación colombiana (Artículo 239 del Código Sustantivo del Trabajo) ha establecido la prohibición a los empleadores de despedir de su puesto de trabajo a la mujer trabajadora en estado de embarazo sin una justa causa comprobada y sin contar con la autorización del Ministerio del Trabajo. A diferencia de la legislación laboral mexicana, la cual no cuenta con un artículo que establezca la prohibición o condicionante para despedir a una mujer embarazada.

La previa autorización para despedir a una mujer embarazada, que 
exige el artículo 240 del Código Sustantivo del Trabajo de Colombia, consiste en un procedimiento previo para la autorización de un despido de una mujer embarazada, el cual se basa en analizar las causas que motivan el despido de la trabajadora, de modo que estas, tengan fundamento en los artículos 62 y 63 del Código Sustantivo del Trabajo y no por motivos discriminatorios hacia la mujer y de igual forma la mujer tendrá derecho de audiencia y defensa en dicho proceso.

En cambio, México, en su legislación no contempla un numeral que disponga una prohibición para despedir a una mujer embarazada, ni un procedimiento previo al despido de una trabajadora, es decir que la estabilidad laboral en México no se contempla reforzada como lo hace Colombia.

Las mujeres trabajadoras en estado de embarazo en ambas legislaciones, tienen derecho a conservar su trabajo, dicho derecho encuentra asidero en la Ley Federal del Trabajo en su Art 170 Fracción VI (México) y el art. 241 del Código Sustantivo del Trabajo (Colombia). Es aquí donde se manifiesta en ambas legislaciones la estabilidad laboral, ya que como se define, es el derecho que tiene el trabajador de conservar su trabajo mientras no incurra en alguna de las causales de despido establecidas por la ley, y es la obligación del empleador de mantener al trabajador en su trabajo.

Como se observa México no cuenta con una estabilidad laboral reforzada en su legislación, como la posee Colombia, teniendo en cuenta los instrumentos internacionales, ambos países han reconocido el derecho que tienen las mujeres embarazadas, a contar con dicha estabilidad en el empleo y sobre todo la protección de no discriminación por razones de género, que su legislación nacional le otorga a las mujeres en los diferentes ámbitos de la vida, en especial, en el ámbito laboral. 


\section{Referencias:}

Asamblea General de las Naciones Unidas. (10 de diciembre de 1948). La Declaración Universal de los Derechos Humanos. 25 de julio 2018, de Naciones Unidas Sitio web: http://www.un.org/es/universaldeclaration-human-rights/

Asamblea Nacional Constituyente. (1991).Constitución Política De Colombia. Recuperado de http://www.alcaldiabogota.gov.co/sisjur/ normas/Norma1.jsp? $\mathrm{i}=4125$

Constitución Política de los Estados Unidos Mexicanos, (1917). Publicada en el Diario Oficial el 5 de febrero de 1917. Recuperada en: https:// www.juridicas.unam.mx/legislacion/ordenamiento/constitucionpolitica-de-los-estados-unidos-mexicanos

Código Sustantivo del Trabajo. (7 de junio de 1951). Colombia. Avance Jurídico Casa Editorial Ltda. Recuperado de http://www. secretariasenado.gov.co/senado/basedoc/codigo_sustantivo trabajo. $\underline{\mathrm{html}}$

Conferencia General de la Organización Internacional del Trabajo. (4 junio 1952). C103 - Convenio sobre la protección de la maternidad. Ginebra. OIT Recuperado de http://www.ilo.org/dyn/normlex/es/f?p $=$ NORMLEXPUB:12100:0::NO::P12100_ILO_CODE:C103

Conferencia General de la Organización Internacional del Trabajo. (4 junio 1952). C102 - Convenio sobre la seguridad social. Ginebra. OIT Recuperado de https://www.ilo.org/dyn/normlex/es/f?p=1000:1 2100:::NO:12100:P12100 INSTRUMENT ID:312247

Conferencia General de la Organización Internacional del Trabajo. (29 de octubre de 1919). C003 - Convenio sobre la protección de la maternidad. Ginebra. OIT Recuperado de http://www.ilo.org/dyn/ normlex/es/f?p=NORMLEXPUB:12100:0::NO::P12100_ILO CODE:C003

Conferencia General de la Organización Internacional del Trabajo. (30 de mayo de 2000). C183 - Convenio sobre la protección de la maternidad. Ginebra. OIT Recuperado de http://www.ilo.org/dyn/ 
normlex/es/f?p=NORMLEXPUB:12100:0::NO::P12100 ILO CODE:C183

Conferencia General de la Organización Internacional del Trabajo. (30 de mayo de 2000). R191 - Recomendación sobre la protección de la maternidad, 2000. Ginebra. OIT Recuperado de http://www.ilo.org/ dyn/normlex/es/f?p=NORMLEXPUB:12100:0::NO::P12100_ILO_ CODE:C183

Congreso de la Unión. ( $1^{\circ}$ de abril de 1970). Ley Federal del Trabajo. México Recuperado de http://www.cnsf.gob.mx/ CUSFELECTRONICA/CUSF/Viewer?filePath=LFT.pdf

Martínez Migueles, M. (2007). Ciencia y arte en la Metodología Cualitativa. México D.F. Trillas.

México, Tribunales Colegiados de Circuito. (2014). Trabajadoras embarazadas y en situación de maternidad. Conforme al Marco Constitucional e Internacional de protección a los Derechos Humanos, al gozar de una tutela especial, entre otros beneficios, cuentan con estabilidad reforzada en el empleo décima época. Gaceta del Semanario Judicial de la Federación. Libro 6, Mayo de 2014, Pág. 2271, recuperado en: https://sjf.scjn.gob.mx/sjfsist/ Documentos/Tesis/2006/2006384.pdf. 
